Review

\title{
Climate Impacts and Adaptation Strategies of the Bangladeshi Coastal Communities
}

\author{
Edris Alam \\ Department of Geography and Environmental Studies, University of Chittagong, Chittagong-4331, Bangladesh
}

Article history

Received: 02-02-2017

Revised: 23-05-2017

Accepted: 27-03-2018

Email: edrisalam@yahoo.com

\begin{abstract}
Bangladesh is considered one of the most vulnerable countries to climate variability, fluctuation and extreme climatic events. Bangladeshi coastal communities are continuously adopting self-instinct survival strategies in order to cope with changing climatic conditions. This paper discusses the impact of climate change on livelihoods and documents current and future adaptation strategies of the Bangladeshi coastal communities from documentary sources. Later, it undertook validation processes of these finding by field visits, observations and Focus Group Discussions (FGDs). The findings suggest that climate change effects on local community may include, but not limited to, livelihood, migration and health in Bangladesh. To offset the effects of extreme climatic events, vulnerable communities are often forced to migrate within the country. The findings of the research indicate that those who migrated to another area were able to secure new places to reside but in locations that made them susceptible to other forms of disaster.
\end{abstract}

Keywords: Climate Change, Effects, Adaptation, Community Resilience, Bangladesh Coast

\section{Introduction}

Climate change is one of the greatest threats to human life and security (Burton et al., 2006; IPCC, 2007; Yamin et al., 2005; Alam et al., 2017). Mitigation of the Green House Gases (GHGs) and adaptation to live with the changing environment are considered two anthropogenic ways for tackling climate change (Fussel and Klein, 2006; IPCC, 2014). Climate change adaptation refers to adjustment of the natural or human systems in response to actual or expected climatic stimuli or their effects, which moderate harms or exploits beneficial opportunities (Perry et al., 2007). Building the capacity to adapt to climate change implies that people must protect themselves against inevitable new and exogenous threats to their health and wellbeing (Collins, 2008). The U.N. Intergovernmental Panel on Climate Change notes that "adaptation to climate change takes place through adjustments to reduce vulnerability or enhance resilience in responses to observed or expected changes in climate and associated extreme weather events" (IPCC, 2014). Coastal hazards (i.e., tropical cyclones and coastal erosion) are regarded as the greatest threats to human life and security in many countries. Bangladesh, which has a predominantly agricultural economy, a rapidly increasing population and a slow economic growth rate, is currently ranked as one of the most prone to natural disasters (WB, 2005). Bangladesh has a coastline over $710 \mathrm{~km}$, joining the vast $47,201 \mathrm{~km}^{2}$ area of coastal plain with the Bay of Bengal (BBS, 2011). The country has 64 administrative districts (BBS, 2011), 19 of which are considered coastal (Karim and Mimura, 2008). The coastal zone accounts for $32 \%$ of the total area of the country (Fig. 1); and $28 \%$ of the population lives in this zone. The landward limit of the coastal zone from the shore is between 30 and $195 \mathrm{~km}$.

For this research, resilience means 'the degree to which individuals able organize themselves on the basis of learning from past disasters and continuous climate change adaptation to provide better future human security and improved risk reduction strategies'. It is known that frequent natural hazards coupled with climate change will present complex development challenges for remote rural communities (CRED, 2011; Twigg and Bhatt, 1998; Ayers, et al., 2014). 


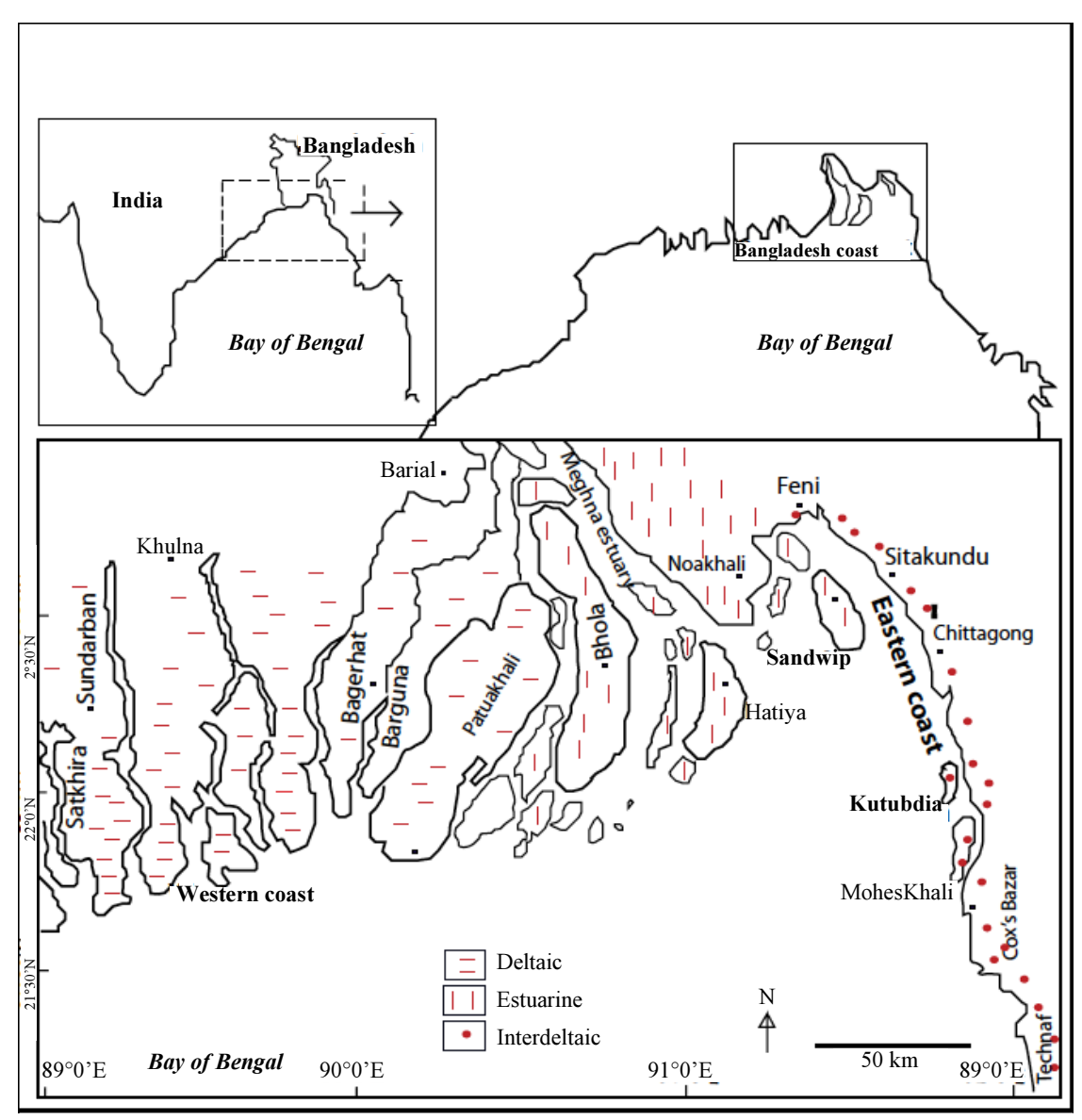

Fig. 1: Location of Bangladesh coast and selected study areas for this research
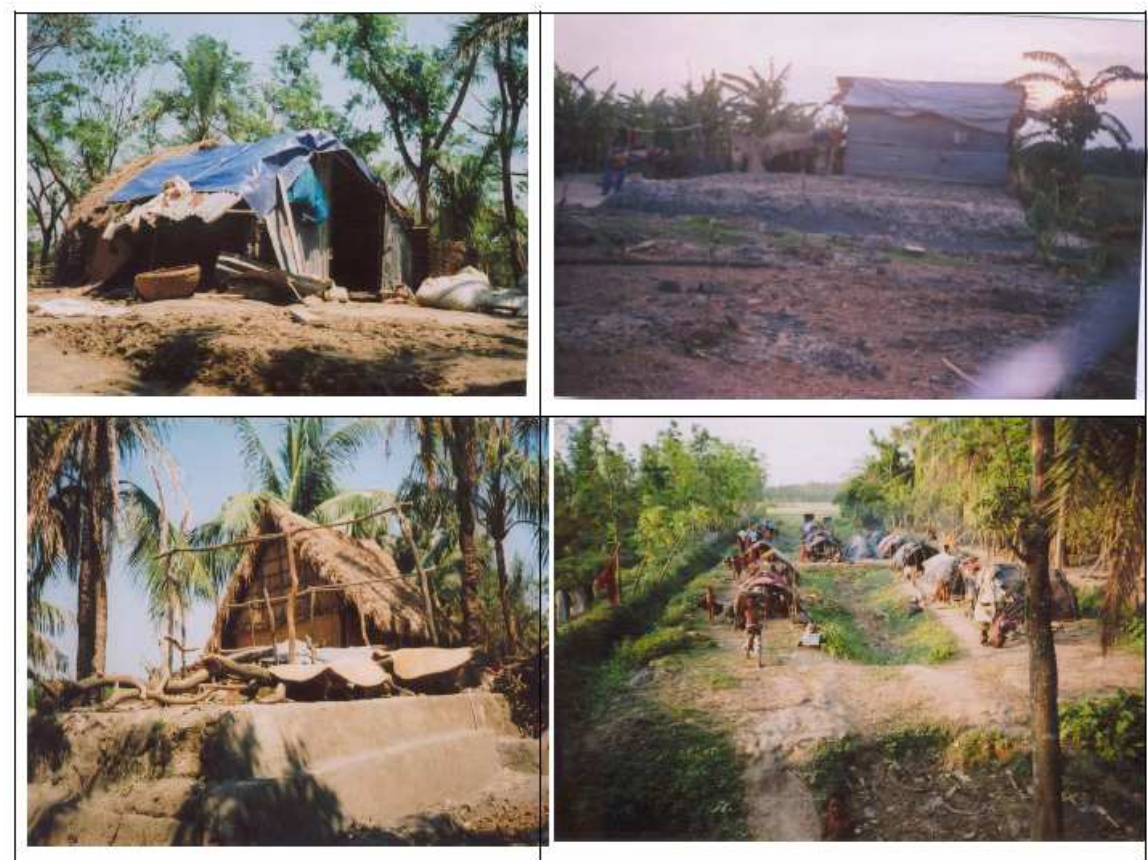

Fig. 2: Devastation to houses and the type of temporary houses after Cyclone Sidr in 2007 (Source: The author) 
The WB (2005) estimates that $97 \%$ of the total area and $99 \%$ of the population of Bangladesh are at risk from multiple hazards such as cyclone, flood, drought, earthquake and tornado. From the early history of human settlement on the Bangladesh coast, many people chose to situate their homes along unstable riverbanks or insecure offshore islands located in the northern end of the Bay of Bengal, where living conditions were affordable and livelihood opportunities plentiful. However, many of these offshore communities (e.g., Sandwip, Kutubdia and Hatiya) have been subjected to frequent tropical cyclones (Fig. 2). In addition, the local communities on these remote islands have been severely affected by coastal erosion. To offset the impact of disasters, the coastal people are continuously applying adaptation strategies for sustaining livelihoods, human habitations and health resilience.

As a signatory of the United Nations Framework Convention on Climate Change (UNFCCC), Bangladesh developed a National Adaptation Program of Actions (NAPA) in 2005. The NAPA identified potential impacts of climate change, vulnerable sectors and geographic areas; and proposed the most important and immediate adaptation actions (Huq, 2011). Three years later, the Ministry of Environment and Forests published the Bangladesh Climate Change Strategy and Action Plan (BCCSAP), a "living document" that aims at developing long-term practical strategies to mitigate climate change risks (MoEF, 2009). Non-Governmental Organizations (NGOs), too, have been making significant contributions in promoting local residents' health, sustainable livelihoods and mitigating disasters in Bangladesh, notably in significantly reducing waterborne diseases and promoting alternative livelihoods among the Bangladeshi coastal communities. For example, the Caritas Bangladesh, an NGOs and its local partner, Sushilon, assisted local communities in southwestern Bangladesh in emptying and cleaning ponds, which are their residents' sole sources of drinking water. The implementation of these programs has markedly decreased the incidence of diarrhea, dysentery and skin diseases, which had been widespread among the local residents (Khan et al., 2011). The hazardaffected communities in Bangladesh are well known to taking their own initiatives (Alam, 2002; Alam and Collins, 2010) to cope with major disruptive events. There is currently a clear absence of grounded research to identify local level climate change and its impacts and only a limited understanding of community level adaptation and coping even though it is known that rural communities do cope with disaster.

In light of the introduction, this research aims to identify reported effects of climate change on life and livelihood of the Bangladeshi coastal communities and subsequent community led adaptation strategies to live with changing climate extremes. After documenting climate extreme impacts and adaptation strategies, this paper comments on aspects of community resilience to climate change and provides subsequent discussion and conclusions.

\section{Reported Effects of Climate Extreme on Bangladeshi Coastal Communities}

Climate change effects may include, but not limited to, livelihood, migration and health (Table 1). This paper only reports those effects that peer reviewed journal articles have attributed to climate change. It attempted to analyse key literature on climate change impact on livelihood, human habitations and health on Bangladesh coast. The real cause of migration, food insecurity and health problems or other social problems often attributed to climate change is difficult to determine because some other factors may also cause these to happen. For example, people may wish to migrate from their homes to other areas not only due to climate change and its associated problems but also for some other pull factors (i.e., job opportunity, education, health and etc.). However, it is impossible to dismiss climate change as one of the main push factors (Luetz, 2013). Bangladeshi communities are vulnerable to climate extreme and other hazards due to a variety of socio-cultural and economic factors.

\section{Community-Led Adaptation Actions}

In order to understand community-led adaptation strategies, the activities of this research can be divided into two phases. In the first phase (December 2015 to February 2016), relevant key literature on climate change adaptation for livelihoods, human habitations and health were collected, collated and analysed. In the second phase (March 2016 to April 2016), two field visits and six FGDs were conducted with local residents in Sandwip and Kutubdia islands (Fig. 1) - the locations where the other authors did not visit. Six FGDs were conducted, which include two in each location, consisting of 10 people in each group (equal number of male and female in each group) at a convenient time and place for the participants. The respondents of the FGDs were randomly selected for interview. The duration of the each FGD was approximately 1 hour. The ages of the participants in the FGDs were over twenty-five. The occupations of the FGDs participants included labourer, local vehicle drivers, farmers, fishermen, housewives and small shopkeepers. 
Table 1: Reported effects of climate extreme on Bangladeshi coastal communities

\begin{tabular}{ll}
\hline Sectors of effects \\
\hline Livelihood & $\begin{array}{l}\text { Food security } \\
\text { Fishing }\end{array}$ \\
& Food diversity \\
Migration & $\begin{array}{l}\text { Forced migration from the } \\
\text { coast to the inland Bangladesh }\end{array}$
\end{tabular}

Forced migration from the coast to adjacent Indian regions

Health Deaths and injuries

Malnutrition
Safe drinking water

Gender dimensions of effects Increase of climate extreme related disease and sickness

Description of effects

Decrease of $r$ ice production

Decrease in fish catch in the Bay of Bengal

and Bangladesh coast Islam ADDIN

Decrease in crop varieties due to intrusion of saline water and monoculture

The inhabitants in the remote island areas of the Bay of Bengal, when lost their habitations due to coastal erosion and storm surge inundation, migrated to adjacent urban areas. They generally formed two types of settlements. These are: (i) slum dwelling within major city areas and (ii) settlements adjacent to the hills. Sea level rise and natural hazard induced displaced people from the Bangladesh coast have taken shelter in adjacent India illegally.

Deaths resulting from cardio-respiratory diseases associated with high and low temperatures Higher malnutrition rate among coastal residents due to the reduction of food diversity Rise of tide levels and frequent coastal flooding Increase salinity in groundwater. Drinking of saline contaminated water increases eclampsia and hyper tension among women in coastal areas

A decrease in women income and stressful social life Mosquito-borne diseases, tick-borne diseases (e.g. malaria, dengue) and air pollution related mortality and morbidity
Sources

Ali (2006)

Islam (2009)

Khan et al. (2011)

Black et al. (2011)

Kartiki, K., (2011)

Mallick and Vogt (2014)

Bose (2013)

Rashid et al. (2013)

Khan et al. (2011)

Khan et al. (2008)

Pouliotte et al. (2009)

Rashid et al. (2013)

Table 2: Community-led adaptation actions of the Bangladeshi coastal communities

\begin{tabular}{|c|c|c|c|}
\hline Adaptation sectors & & Description of adaptation & Sources \\
\hline \multirow[t]{6}{*}{ (1) Livelihood } & $\begin{array}{l}\text { Changing rice crop farming } \\
\text { to non-rice farming }\end{array}$ & $\begin{array}{l}\text { Farming of different varieties of crops, cultivation } \\
\text { of jute, wheat, plum and different types of pulses }\end{array}$ & Sarkar et al. (2011) \\
\hline & $\begin{array}{l}\text { Migrating for jobs mainly } \\
\text { to Middle }\end{array}$ & $\begin{array}{l}\text { Eastern countries or other affordable countries } \\
\text { (i.e., Malaysia etc.) }\end{array}$ & $\begin{array}{l}\text { Field visits, observations } \\
\text { and discussion with local } \\
\text { communities by author }\end{array}$ \\
\hline & $\begin{array}{l}\text { Increasing involvement in } \\
\text { a variety of income sources }\end{array}$ & $\begin{array}{l}\text { Earning money by wage labour, small business, } \\
\text { construction works and livestock farming }\end{array}$ & Pouliotte et al. (2009) \\
\hline & Selling land and taking loan & $\begin{array}{l}\text { Selling land and taking loans (especially poor } \\
\text { households) }\end{array}$ & Alam et al (2012) \\
\hline & Gender dimensions & $\begin{array}{l}\text { Women are forced to take difficult jobs outside } \\
\text { their comfort zone. }\end{array}$ & Abedin et al. (2013) \\
\hline & $\begin{array}{l}\text { Obtaining support from } \\
\text { relatives and social networks }\end{array}$ & $\begin{array}{l}\text { Support by relatives and social networks to } \\
\text { offset losses and to cope with devastations }\end{array}$ & $\begin{array}{l}\text { Questionnaire surveys } \\
\text { and FGDs }\end{array}$ \\
\hline \multirow{5}{*}{$\begin{array}{l}\text { (2) Human } \\
\text { habitations }\end{array}$} & Raising homestead & Low-lying coastal and island inhabitants often raise & Alam (2003a) \\
\hline & and plinth & $\begin{array}{l}\text { homestead and plinth much higher than mainland } \\
\text { people to mitigate severe effects of coastal flooding }\end{array}$ & Alam (2003b) \\
\hline & Planting trees & $\begin{array}{l}\text { Planting trees around the house to reduce the } \\
\text { intensity of storm surge attack }\end{array}$ & \\
\hline & Modifying of houses & $\begin{array}{l}\text { Building a special tent-type of shed for those who } \\
\text { have lost their houses }\end{array}$ & $\begin{array}{l}\text { Alam and Collins } \\
(2010)\end{array}$ \\
\hline & Changing house locations & $\begin{array}{l}\text { - The changes of housing locations from the coast } \\
\text { of offshore island to inner part of the island or } \\
\text { migration to the adjacent mainland } \\
\text { - Those people changes house to the adjacent mainland } \\
\text { mostly able to manage settlement in unstable slope of } \\
\text { hills, non-habited forest hills, coastal and river margins in } \\
\text { the adjacent mainland or cities these areas otherwise } \\
\text { unused and publicly owned }\end{array}$ & $\begin{array}{l}\text { Field visits, observations } \\
\text { and discussion with local } \\
\text { communities by author }\end{array}$ \\
\hline (3) Health & $\begin{array}{l}\text { Adopting household } \\
\text { coping strategies }\end{array}$ & $\begin{array}{l}\text { Season specific household levels strategies preventing } \\
\text { sickness and diseases from extreme heat, cold and } \\
\text { precipitation }\end{array}$ & Haque et al. (2013) \\
\hline
\end{tabular}




\section{$90^{\circ} \mathrm{E}$}

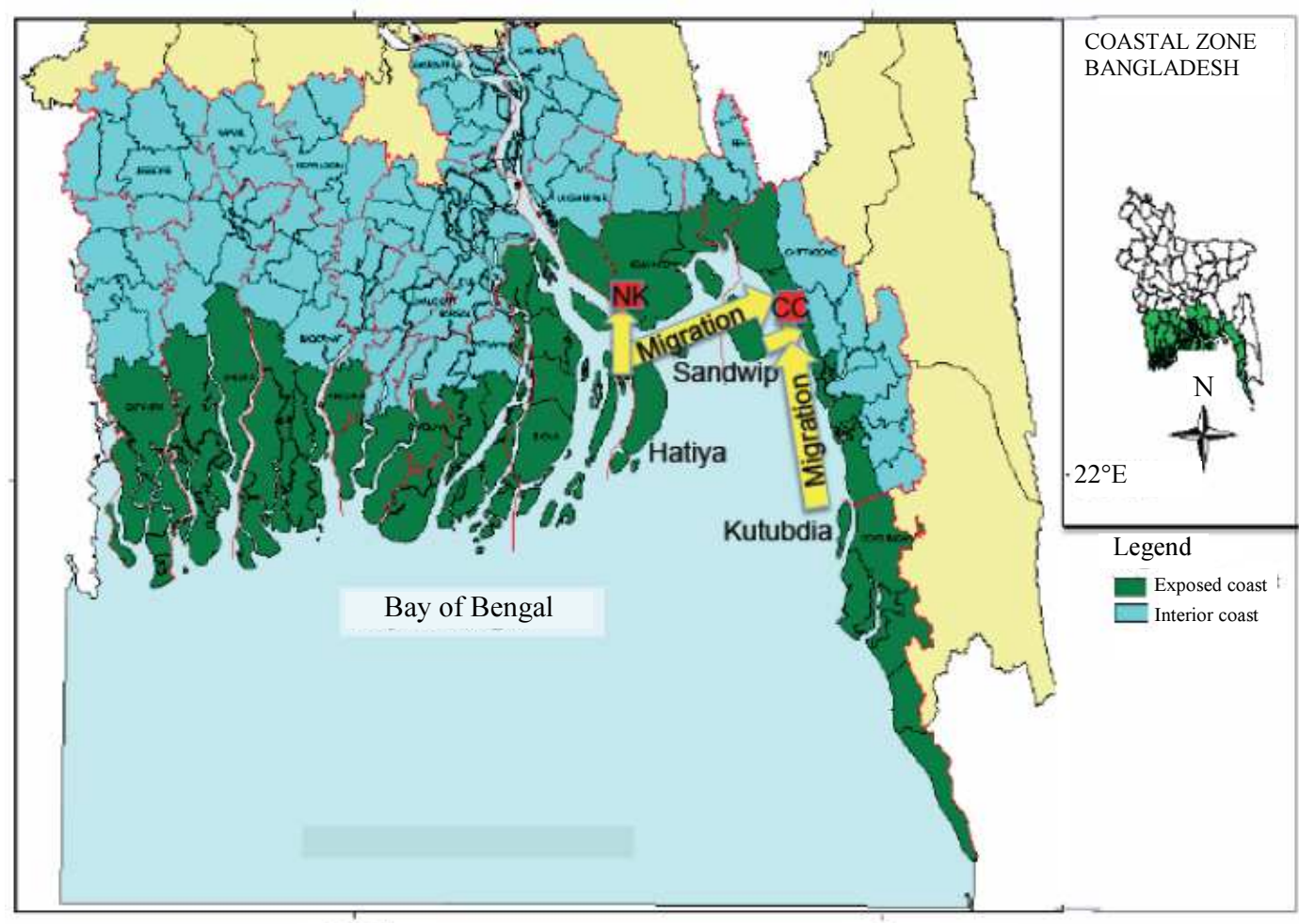

$90^{\circ} \mathrm{E}$ $92^{\circ} \mathrm{E}$

$92^{\circ} \mathrm{E}$

Fig. 3: Location of highly vulnerable areas to tropical cyclones. The yellow solid arrows show the flow direction of disaster-induced migration from the offshore islands to the mainland of Bangladesh. $\mathrm{CC}=$ Chittagong City, $\mathrm{NK}=$ Noakhali

Climate change adaptation may be divided into two categories. These are: Institution led adaptation strategies and community led adaptation strategies. This research reports three main sectors (Table 2) of adaptations (i.e., livelihood, human habitation and health) undertaken by communities, which were adopted as responses to tropical cyclone hazards, salinity intrusion into inland areas and other extreme climatic conditions. Apart from the initiatives taken by the national authorities and by non-governmental organizations, coastal community members have taken it upon themselves to find ways to adapt to the heightened risk of climate-related natural disasters. The review suggests that hazard-affected people have employed a variety of short-term and long-term actions to cope with disastrous conditions (Table 2). However, migration is one of the most common adaptation strategies following a disaster, primarily as a result of lost livelihood and the fear of the recurrence of another such calamity (Brook and Paul, 2003). Focus group discussions and field visits revealed that many coastal communities membersparticularly those living on daily earnings who own neither land nor other property-had change their residence from the offshore islands, which they had judged to be insecure, to areas on the mainland, which they had presumed to be more safe (Fig. 3).

\section{Community Resilience to Climate Change}

Community resilience to climate change implies that the return of the functions of life and livelihoods of climatic stress affected community to a normal standard of living with the observed changes in climate and/or future abrupt changes in climate. The concept of resilience needs to be understood in three ways for better policy implications (Tanner et al., 2014). First, it is important to identify its 'contested nature'. The term resilience depends on differential 'social values' we prioritorise and how resources are to be allocated to sustain it (O'Brien and Wolf, 2010). The execution of resilience concept may depend on several factors: (1) Types of activities; (2) to whom these to be implemented; (3) agents of decisionmaking; and (4) cultural context of implement at ion (Cote and Nightingale, 2012). Second, it needs to be considered how activities and institutions determine political economy of climate change resilience. This allows us to understand who are going to be benefitted by resilience activities, power relation in implementing 
activities, distribution of benefits, varying access to resources and concurrent inequality in society (Béné et al., 2012; Beymer-Farris et al., 2012). Third, climate resilience should be considered by considering varying level of climate impacts and capacity of different social groups to respond to climate change. The factors of impact and response to climate change may include "levels of on-the-ground social inequality, rights and unequal access to resources, poverty, poor infrastructure, lack of representation and inadequate systems of social protection, planning and risk management" (Tanner et al., 2014).

There is less understanding of community resilience to climate change. The reason for this is that the lack of understanding difference between community led autonomous and institution led imposed climate resilience activities. One example of community led or autonomous climate resilience activity is that the Bangladeshi coastal communities are by generations used to planting trees around the house to reduce the intensity of storm surge attack. One the other hand, the local communities are also transforming their rice farming land into mango orchard with the support of external organizations. However, in the past it is documented that external programmes did not bring much positive impact on local coping strategies with disasters in Bangladesh (Alam and Collins, 2010; Haque and Zaman, 1993). Although it seems that community led resilience activities in responding to tropical cyclones are more acceptable, these would require further validation to test their sustainability.

Indeed, firsthand evidence from coastal Bangladesh-an area frequently affected by tropical cyclones, riverbanks and coastal erosion-indicates that near-distance and far distant out-migration is a continuous adaptation action. The firsthand evidence was collected through frequent field visits and informal discussions with local communities in varying type of hazard prone areas of Bangladesh. Some people migrating from the offshore islands form squatter settlements along the unstable hill slopes in and adjacent to the Chittagong City (Fig. 4). Torrential rainfall in the deforested hills in Chittagong City in June 2007 caused landslides that affected 2,680 families and claimed 137 lives. An analysis of the settlement history of the victims of the landslides found that they had migrated from the offshore island areas to the unstable slopes in the Chittagong City hillside. Three-quarters of those who had migrated to these unstable areas had previously lost their houses as a result of the April 1991 cyclone or due to coastal erosion. Of those who perished in the 2007 landslides, the death toll for women and children far exceeded that of adult males (Chisty, 2014).

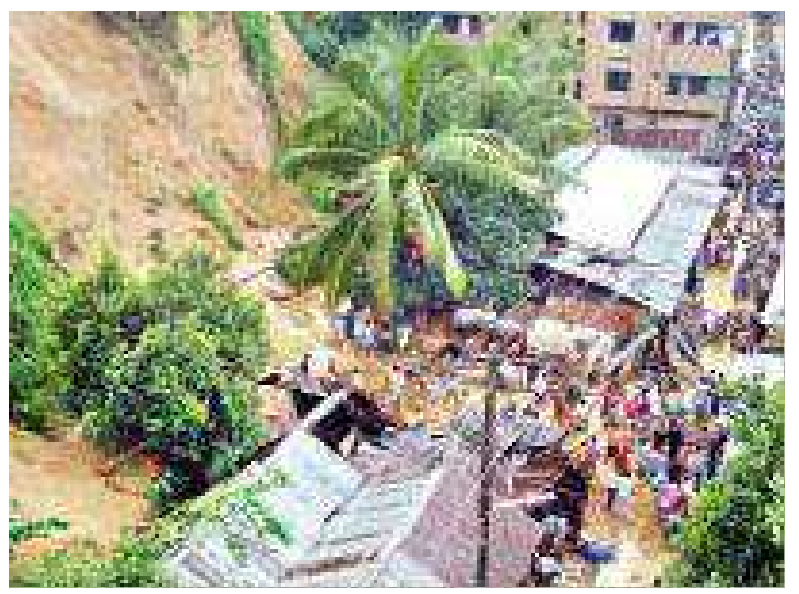

Fig. 4: Houses adjacent to the susceptible hill at Kusumbagh area in Chittagong City (Source: The author, 2007)

\section{Conclusion}

The research suggests that the Bangladeshi coastal community is taking continuous adaptation actions to survive the slow onset and sudden changes in climate conditions. Human induced climate change is now undeniable. A growing number of researches from around the world has evidenced symptoms and impacts of climate change (CCC, 2009; Khan et al., 2011; Luetz, 2013). Climate change and its associated impacts are experienced through livelihood changes (i.e. decrease of rice production, fish catch in the Bay of Bengal and Bangladesh coast, decrease in crop varieties due to intrusion of saline water and monoculture, etc.), changes in human settlement (i.e. forced migration from the coast to the inland Bangladesh and to adjacent Indian regions) health and wellbeing (i.e. malnutrition, safe drinking water, a decrease in women income and stressful social life, increase of climate extreme related disease and sickness, etc.) of the Bangladeshi coastal communities. The Bangladeshi coastal communities are adopting selfinstinct adaptation strategies to these climatic impacts. These include changing rice crop farming to non-rice farming, migrating to other countries for livelihood purposes, raising homestead and plinth, modification of houses, season specific household levels strategies preventing sickness and diseases from extreme heat, cold and precipitation, etc. Changing location of houses from hazard-prone coastal areas to the mainland is one form of adaptation action the coastal community has undertaken. However, the ongoing research on disaster-induced migration indicates that the migrants were not able to obtain secure land but rather settled in an area that is, itself, prone to another form of disaster. The specific audiences of this research will be research academics and institutions, Government of Bangladesh, NonGovernmental Organizations in Bangladesh along with 
other international developmental organizations working on disaster risk reduction, climate change adaptation and sustainable development sectors in Bangladesh and elsewhere in the world.

\section{Acknowledgment}

Dr Edris Alam thanks the University of Chittagong for approval of higher study leave at UNSW Australia. He acknowledges substantial input and correction received from anonymous reviewers and friends who wanted to be anonymous. Thanks are extended to the Disaster Action and Development Organisation (DADO), Bangladesh for helping data collection in Bangladesh.

\section{Ethics}

There are no ethical issues associated with this paper as all the respondents of interviews remain anonymous and the participants who contributed data/information did so in full consciousness of the fact of what the research was about.

\section{References}

Abedin, M.A., U. Habiba and R. Shaw, 2013. Gender and Climate Change: Impacts and Coping Mechanism of Women and Special Vulnerable Groups. In: Climate Change Adaptation Actions in Bangladesh, Shaw, R., F. Mallick and A. Rahman (Eds.), Springer, Tokyo, pp: 33-44.

Alam, E., 2002. Post cyclone adjustment process: The case of Sandwip, Bangladesh. MSc Thesis, University of Dhaka, Bangladesh.

Alam, E., 2003a. Coping with cyclone: An occupational group perspective. J. Asiatic Society Bangladesh (Humanities), 48: 59-74.

Alam, E., 2003b. Post cyclone adjustment process: Basic needs perspective. Oriental Geographer, 47: 47-60.

Alam, E. and A.E. Collins, 2010. Cyclone disaster vulnerability and response experiences in coastal Bangladesh. Disasters, 34: 931-954.

Alam, E., S. Momtaz and A. Collins, 2012. Adaptation actions and human security in Bangladesh: An analysis of disaster resilient response mechanisms in the context of coastal hazards. Australian Meteorological and Oceanographic Society Annual Conference, Jan. 31-Feb. 2, Sydney, Australia.

Alam, E., S. Momtaz, H.B. Bhuiyan and S.N. Baby, 2017. Climate change impacts on the Bangladesh coast: Perspective on tropical cyclones, sea level rise and social vulnerability, in Islam, N., Amstel, A., Bangladesh 1: Climate Change Impacts, Mitigation and Adaptation in Developing Countries, Series: Springer Climate Change, pp: 190.
Ali, A.M.S., 2006. Rice to shrimp: Land use/land cover changes and soil degradation in Southwestern Bangladesh. Land Use Policy, 2006: 421-435.

Ayers, J., S. Huq, H. Wright, A.M. Faisal and S.T. Hussain, 2014. Mainstreaming climate change adaptation into development in Bangladesh, Climate Dev., 6: 293-305. DOI: $10.1080 / 17565529.2014 .977761$

BBS, 2011. Bangladesh population census-2011. Bangladesh Bureau of Statistics (BBS), Government of Bangladesh, Dhaka.

Béné, C., R. Wood, A. Newsham and M. Davies, 2012. Resilience: New utopia or new tyranny. Working Paper 405, Institute of Development Studies, Sussex.

Beymer-Farris, B.A., T.J. Bassett and I. Bryceson, 2012. Resilience in the Cultural Landscape. In: Plieninger, T. and C. Bieling (Eds.), Cambridge University Press, pp: 283-299.

Black, R., S.R.G. Bennett and S.M. Thomas, 2011. Migration as adaptation: Mobility can bring opportunities for coping with environmental change. Nature, 478: 477-479.

Bose, S., 2013. Sea-level rise and population displacement in Bangladesh: Impact on India. Maritime Affairs: J. Nat. Maritime Found. India, 9: 62-81.

Brook, V.T. and B.K. Paul, 2003. Public response to a tornado disaster: The case of Hoisington, Kansas. Proceedings of the Applied Geography Conferences, pp: 343-351.

Burton, I., E. Diringer and J. Smith, 2006. Adaptation to climate change: International policy options. Prepared for the Pew Center on Global Climate Change, Pew Center on Global Climate Change.

CCC, 2009. Characterizing long-term changes of Bangladesh climate in context of agriculture and irrigation. Climate Change Cell, DoE, MoEF, Component 4b, CDMP, MoFDM, Dhaka.

Chisty, K.U., 2014. Landslide in Chittagong City: A perspective on hill cutting. J. Inst. Planners, 7: 1-17.

Collins, A.E., 2008. Health security or climate change adaptation? What do we really mean by disaster risk reduction in times of disease? Proceedings of the International Disaster and Risk Conference, (DRC' 08), Davos, Switzerland.

Cote, M. and A. Nightingale, 2012. Resilience thinking meets social theory: Situating social change in Socio-Ecological Systems (SES) research. Progress Human Geography, 36: 475-489.

CRED, 2011. EM-DAT 2011: The OFDA/CRED International Disaster Data base-Brussels: University Catholique de Louvain.

Fussel, H.M. and R.J.T. Klein, 2006. Climate change vulnerability assessments: An evolution of conceptual thinking. Climate Change, 75: 301-329. 
Haque, C.E. and M.Q. Zaman, 1993. Human responses to riverine hazards in Bangladesh: A proposal for sustainable floodplain development. World Dev., 21: 93-107.

Haque, M.A., A. Budi, A.A. Malik, S.S. Yamamoto and V.R. Louis et al., 2013. Health coping strategies of the people vulnerable to climate change in a resource-poor rural setting in Bangladesh. BMC Public Health, 13: 1-11.

Huq, S., 2011. Lessons of climate change, stories of solutions. Bangladesh: Adaptation. Bull. Atomic Scient., 67: 56-59.

IPCC, 2007. Climate Change 2007: Impact, adaptation and vulnerability. Contribution of Working Group II to the fourth assessment report of the IPCC. Cambridge University Press, Cambridge.

IPCC, 2014. Summary for Policymakers. In: Climate Change 2014: Impacts, Adaptation and Vulnerability. Part A: Global and Sectoral Aspects. Contribution of Working Group II to the Fifth Assessment Report of the Intergovernmental Panel on Climate Change. Field, C.B., V.R. Barros, D.J. Dokken, K.J. Mach and M.D. Mastrandrea et al. (Eds.), Cambridge University Press, Cambridge, United Kingdom and New York, NY, USA, pp: 1-32.

Islam, M.M., 2009. Living on the edge: Relating climate change impacts to the poverty in small-scale coastal fisheries of Bangladesh, IOP conference Series: Earth and Environmental Science 6, Climate Change: Global Risks, Challenges and Decisions, Copenhegen, Denmark.

Karim, M.F. and N. Mimura, 2008. Impacts of climate change and sea-level rise on cyclonic storm surge floods in Bangladesh. Global Environ. Change, 18: 490-500.

Kartiki, K., 2011. Climate change and migration: A case study from rural Bangladesh. Gender Dev., 9: 23-38.

Khan, A., K.S. Mojumder, S. Kovats and P. Vineis, 2008. Saline contamination of drinking water in Bangladesh. Lancet, 371: 385-385.

Khan, A.E., W.W. Xun, H. Ahsan and P. Vineis, 2011. Climate change, sea-level rise and health impacts in Bangladesh. Environ.: Sci. Policy Sustainable Dev., 53: 18-33.
Luetz, J.M., 2013. Climate migration: Preparedness informed policy opportunities identified during field research in Bolivia, Bangladesh and Maldives. PhD Thesis, Institute of Environmental Studies, The University of New South Wales, Australia.

Mallick, B. and J. Vogt, 2014. Population displacement after cyclone and its consequences: Empirical evidence from coastal Bangladesh. Nat. Haz, 73: 191-212.

MoEF, 2009. Bangladesh climate change strategy and action plan 2009. Ministry of Environment and Forests, Governmet of the People's Republic of Bangladesh, Dhaka, Bangladesh.

O'Brien, K.L. and J.A. Wolf, 2010. A values-based approach to vulnerability and adaptation to climate change. WIREs Climate Change, 1: 232-242.

Perry, M., O. Canziani, J. Palutikof, P.V.D. Linden and C. Hanson, 2007. Climate change 2007: Impacts, adaptation and vulnerability. Contribution of the working group 11 to the Fourth Assessment Report of the Intergovernmental Panel on Climate Change.

Pouliotte, J., B. Smit and L. Westerhoff, 2009. Adaptation and development: Livelihoods and climate change in Subarnabad, Bangladesh. Climate Dev., 1: 31-46.

Rashid, F.H., S. Gani and M. Sarker, 2013. Urban Poverty, Climate Change and Health Risks for Slum Dwellers in Bangladesh. In: Climate Change Adaptation Actions in Bangladesh, Shaw, R., F. Mallick and A. Rahman (Eds.), Springer, Tokyo.

Sarkar, M.A.R., K. Alam and J. Gow, 2013. Assessing the determinants of rice farmers' adaptation strategies to climate change in Bangladesh. Int. J. Climate Change Strategies Manage., 5: 382-403.

Tanner, T., D. Lewis, D. Wrathall, R. Bronen and N. Cradock-Henry et al., 2014. Livelihood resilience in the face of climate change. Nature Climate Change.

Twigg, J. and M. Bhatt, 1998. Understanding Vulnerability: South Asian Perspective. 1st Edn., Intermediate Technology Publications, London.

WB, 2005. Natural disaster hotspots: A global risk analysis, Disaster Risk Management Series No.5. The World Bank, Washington DC.

Yamin, F., A. Rahman and S. Huq, 2005. Vulnerability, adaptation and climate disasters: A conceptual overview. Institute of Development Studies (IDS) Bulletin01. 